This item was submitted to Loughborough's Research Repository by the author.

Items in Figshare are protected by copyright, with all rights reserved, unless otherwise indicated.

\title{
Development and workflow of a continuous protein crystallization process: A case of lysozyme
}

\section{PLEASE CITE THE PUBLISHED VERSION}

https://doi.org/10.1021/acs.cgd.8b01534

\section{PUBLISHER}

(C) American Chemical Society

\section{VERSION}

AM (Accepted Manuscript)

\section{PUBLISHER STATEMENT}

This document is the Accepted Manuscript version of a Published Work that appeared in final form in Crystal Growth and Design, copyright $@$ ( American Chemical Society after peer review and technical editing by the publisher. To access the final edited and published work see https://pubs.acs.org/doi/10.1021/acs.cgd.8b01534.

\section{LICENCE}

CC BY-NC-ND 4.0

\section{REPOSITORY RECORD}

Yang, Huaiyu, Wenqian Chen, Peter Peczulis, and Jerry Y.Y. Heng. 2019. "Development and Workflow of a Continuous Protein Crystallization Process: A Case of Lysozyme”. figshare. https://hdl.handle.net/2134/37651. 
The development and workflow of a continuous protein crystallisation process: A case of lysozyme

Huaiyu Yang, ${ }^{a}$ Wenqian Chen, ${ }^{\text {a }}$ Peter Peczulis, ${ }^{\text {a }}$ and Jerry Y. Y. Heng ${ }^{a} *$

a Department of Chemical Engineering, Imperial College London, South Kensington Campus London SW7 2AZ, UK

*corresponding author: jerry.heng@imperial.ac.uk

\begin{abstract}
In the present work, a workflow on the development of a continuous protein crystallisation is introduced, with lysozyme as a model protein, from micro L screening experiments, to small scale batch crystallisation experiments in a shaking crystallisation platform, and to batch and continuous crystallisation experiments in an oscillatory flow platform. The lysozyme crystallisation investigated were for a concentration range from 30 to $100 \mathrm{mg} / \mathrm{mL}$, shaking conditions from 100 to $200 \mathrm{rpm}$ in the batch shaking crystallisation platform, and oscillatory conditions with amplitude $\left(x_{0}\right)$ from 5 to $30 \mathrm{~mm}$ and frequency $(f)$ from 0.1 to $1.0 \mathrm{~Hz}$ in the batch oscillatory flow crystallisation platform. We propose the use of the Reynold's number $\left(R_{e}\right)$ for scaling up of the process from the shaking batch to the continuous oscillatory flow platform. Additionally, it is shown that the nucleation rate increased with increase in concentration of initial lysozyme solution, or increase in shear rate, inducing smaller size of lysozyme crystals. These indicate that continuous crystallisation platforms may offer advantages to the downstream bioprocessing of proteins.
\end{abstract}

\title{
Introduction
}

There is an acceleration in the development of biopharmaceuticals as next generation therapeutics, with sales of biopharmaceuticals and biotherapy from only Humira, Remicade, and Enbrel exceeding $\$ 18$ billion in US in 2015. Protein therapy is expected to create about 
\$250 billion in savings over the next 10 years. ${ }^{1}$ Manufacturing biopharmaceuticals in a cost effective and reliable route becomes a major industrial challenge for meeting the rapidly growing demands of protein-based medicines. Crystallisation of proteins as one-step operation is more efficient, leading to higher purity protein than conventional purification techniques, such as chromatography. ${ }^{2-4}$ Protein crystals are more stable and are advantageous in terms of storage, formulation and drug delivery. ${ }^{2,5}$

The research for protein crystallisation traditionally focuses on the growth of single protein crystals for determination of their structures by crystallography, ${ }^{6}$ which can reveal important information on their biological functions. ${ }^{7}$ Crystallisation experiments of hanging drop and sitting drop in scales of hundreds of $\mathrm{nL}$ to several $\mu \mathrm{L}$ with high-through screening are used to find the crystallisation conditions of a target protein. ${ }^{8-10}$ The screening of protein crystallisation identifies suitable buffer solutions for stabilising the protein molecules, suitable precipitants for generating nucleation of the protein. However, protein crystallisation remains a challenge due to their huge and complex 3D molecular structure as well as purity of the protein from broth solution. ${ }^{11}$ The crystallisation of protein is also influenced by $\mathrm{pH}^{12}$ ionic strength, ${ }^{13}$ concentration of PEG, ${ }^{14}$ magnetic fields ${ }^{15}$ and etc. Successful screening experiments are a starting point for the batch protein crystallisation, which offer the suitable $\mathrm{pH}, \mathrm{PEG}$, salt for growing crystals, and the basic understanding of the supersaturations and growth rates. However, the kinetics of screening crystallisation condition can be totally different with the batch crystallisation condition, since the concentration of protein in the droplet during vapour diffusion changes over time. A limited number of work have reported the scaling up of crystallisations for different proteins: Iysozyme and lipase with volume of $5 \mathrm{~mL}-1 \mathrm{~L},{ }^{16}$ FabC225 with $5 \mathrm{~mL}-100 \mathrm{~mL}$ in unbaffled stirred tank, ${ }^{17}$ lysozyme and mAb01 product with $150 \mathrm{~mL}$ in product removal tank ${ }^{18}$ and ovalbumin in bottle with $250 \mathrm{~mL} .{ }^{19}$

Continuous manufacturing connecting reaction, crystallisation and formulation have been documented to improve the efficiency of pharmaceutical manufacturing, ${ }^{20,21}$ drawing interests from both the academics and pharmaceutical industrials. Continuous crystallisation platforms, 
like mixed-suspension mixed-product-removal (MSMPR), batch moving fluid oscillatory baffled crystallizer (MFOBC), continuous oscillatory flow crystallizers (COFC) 22,23 and etc. have been developed and applied to many small organic pharmaceuticals. The knowledge of continuous oscillatory flow crystallisation on organic pharmaceutical molecules also contributes to the develop and design of protein crystallisation process, i.e. crystallisation of insulin in oscillatory flow glass capillaries ${ }^{3}$ and crystallisation of lysozyme in meso oscillatory flow reactor. ${ }^{24}$ However, to our knowledge, there is neither continuous oscillatory flow crystallisation research reported for any protein nor the development workflow for a process from shaking batch to continuous oscillatory flow crystallisation. This work will introduce a basic workflow for batch to continuous crystallisation of protein, for scaling up from $\mu \mathrm{L}$ to orders of magnitude larger scale. The Reynolds numbers, crystallisation time and the resident time, as key references, are compared among several crystallisation platforms. Lysozyme (as a model protein) was used to demonstrate this crystallisation workflow from batch shaking tube/crystalliser (BSC) to batch oscillatory flow tube/crystalliser (BOFC) to continuous oscillatory flow tube/crystalliser (COFC), investigated at concentrations from 30 to $100 \mathrm{mg} / \mathrm{mL}$, with shaking conditions from 100 to 200 $\mathrm{rpm}$, and oscillatory conditions with amplitude $\left(x_{0}\right)$ from 5 to $30 \mathrm{~mm}$ and frequency $(f)$ from 0.1 to $1.0 \mathrm{~Hz}$. The size and quality of lysozyme crystals (product) obtained during the steady state in continuously crystallisation experiment were compared with starting (feed) materials.

\section{Experimental}

Lysozyme from chicken egg white (purity $\geq 90 \%, \geq 40,000$ units/mg protein), sodium acetate (purity $>99 \%$ ), sodium chloride (purity $>99.5 \%$ ) and glacial acetic acid (purity $>99.5 \%$ ) were purchased from Sigma Aldrich and used without further purification. Distilled water was used.

Buffer solution was prepared as $0.1 \mathrm{M}$ sodium acetate in deionized water at $\mathrm{pH} 4.8$ adjusted by addition of acetic acid. The lysozyme solutions with concentration of 30 to $100 \mathrm{mg} / \mathrm{mL}$ were prepared by dissolving lysozyme in a sodium acetate buffer solution, and the precipitant solution was $100 \mathrm{mg} / \mathrm{mL} \mathrm{NaCl}$ in buffer solution. All solutions were filtered with a $0.2 \mu \mathrm{m}$ filter. 
The crystallisation experiments were performed in platforms of batch shaking tube/crystalliser (BSC) and batch and continuous oscillatory flow tube/crystalliser (BOFC and COFC) respectively. The crystallisation solutions were mixed with 1:1 volume ratio of the lysozyme solution 30 - 100 $\mathrm{mg} / \mathrm{mL}$ and the precipitant solution. 2 to 4 experiments were repeated for each crystallisation condition at $20 \pm 1^{\circ} \mathrm{C}$.

Table 1 Lysozyme crystallisation conditions for various platforms

\begin{tabular}{llrrrrrrr}
\hline Exp. & Platform & $\begin{array}{r}C \\
(\mathrm{mg} / \mathrm{mL})\end{array}$ & $\begin{array}{r}\omega \\
(\mathrm{rpm})\end{array}$ & $\begin{array}{r}f \\
(\mathrm{~Hz})\end{array}$ & $\begin{array}{r}x_{0} \\
(\mathrm{~mm})\end{array}$ & $\begin{array}{r}Q \\
(\mathrm{~mL} / \mathrm{min})\end{array}$ & $\begin{array}{r}\text { No. } \\
\text { of Exp. }\end{array}$ & $R_{e}$ \\
\hline I & BSC & $50-90$ & $100-200$ & - & - & - & 18 & $45-90$ \\
II & BOFC & $30-100$ & & 0.5 & 20 & - & $16^{*}$ & 212 \\
III* & BOFC & 50 & & $0.1-1$ & 20 & - & $16^{*}$ & $42-424$ \\
IV* & BOFC & 50 & & 0.5 & $5-30$ & - & $13^{*}$ & $53-318$ \\
V & COFC & 50 & & 0.5 & 20 & 0.1 & 2 & $\sim 212$ \\
\hline
\end{tabular}

*The numbers of these three experiments include the same experiments at $0.5 \mathrm{~Hz}-20 \mathrm{~mm}$ with $C$ at $50 \mathrm{mg} / \mathrm{mL}$. $C$ : initial concentration of lysozyme solution.

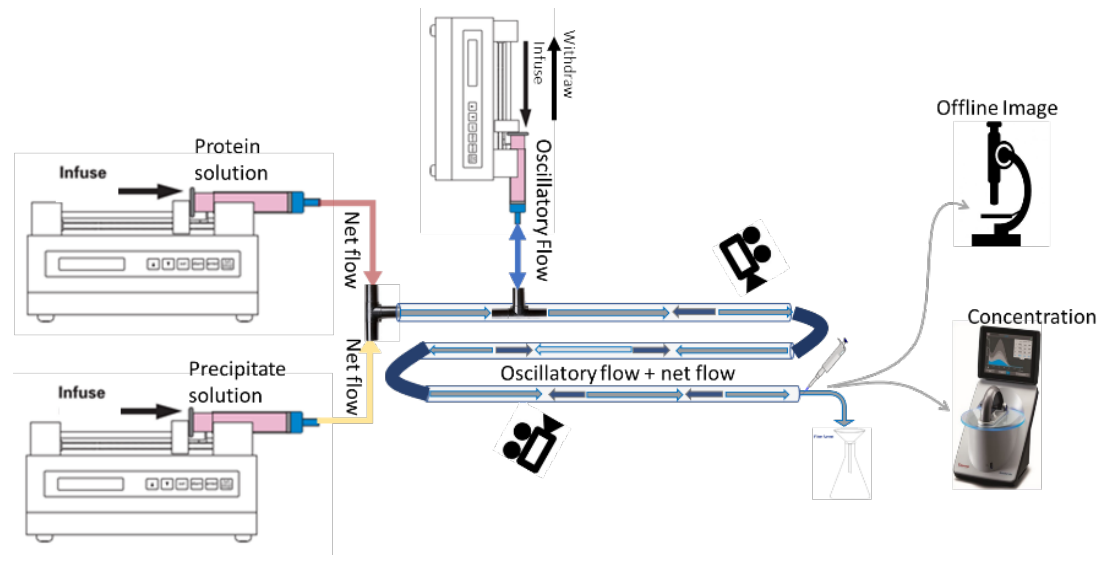

Figure 1 Schematic of the COFC set-up. Protein and precipitation solutions were feed from two syringe pumps, respectively, and the oscillatory flow was generated by another syringe pump.

In the BSC experiments, $0.5 \mathrm{~mL}$ crystallisation solution in each Eppendorf tube was shaken on an orbital shaking plate at 100, 150 and $200 \mathrm{rpm}$. A PVC tube of $27 \mathrm{~cm}$ length and $3 \mathrm{~mm}$ internal 
diameter was used in BOFC, with volume about $2 \mathrm{~mL}$, which was connected to the pumps shown in Figure 1. The crystallisation solutions in the PVC tube were oscillated with, $x_{0}, 5-30$ $\mathrm{mm}$, and, $f, 0.1-1.0 \mathrm{~Hz}$, shown in Table 1. In the COFC, crystallisation solutions were mixed by connecting two syringe pumps (Figure 1), which were filled with the protein and precipitant solutions separately. The solutions were pumped with a net flow rate of $0.1 \mathrm{~mL} / \mathrm{min}$ in total to a PVC tube (volume about $20 \mathrm{~mL}$ ) of about $300 \mathrm{~cm}$ length and $3 \mathrm{~mm}$ internal diameter. The oscillations were generated by another one or two syringe pumps with, $x_{0}, 20 \mathrm{~mm}$, and, $f, 0.5$ $\mathrm{Hz}$. Samples of $2 \mu \mathrm{L}$ were taken from crystallisation solution every 15 or 30 minutes up to 180 and 360 minutes in batch and continuous crystallisation experiments, respectively. Concentrations of the samples were determined by Nanodrop One (Thermo Scientific) and offline images were recorded by a microscope (Olympus cx41) connected to a digital camera (Moticam 5.0MP).

The crystallisation solution in COFC was continuously pumped out and recovered on a $45 \mathrm{~mm}$ diameter filter with a filtration paper attached (Whatman ${ }^{\circledR}$ qualitative filter paper, Grade 4, circles). The funnel was connected to a continuously running vacuum pump. The collected crystal samples were dried in a fume hood at room temperature for two days. Crystal samples were then dispersed in pure ethanol, placed in a sonication water bath (Cole-Parmer 3 Liter Ultrasonic) with a frequency output $40 \mathrm{kHz}$ for $30 \mathrm{~s}$ at room temperature, prior to determination of size distribution using a Malvern 2000.

The bioactivity of lysozyme crystals (product) obtained was tested with the Lysozyme Activity Kit (Sigma Aldrich), based on the cell disruption (lysis) of Micrococcus lysodeikticus cells (substrate) from an initial concentration of approximately $0.18 \mathrm{mg} / \mathrm{mL}$. After addition of the the lysozyme solution into the substrate solution, the reaction was recorded by measuring the decrease in absorbance at $450 \mathrm{~nm}$ with Nanodrop One (Thermo Scientific) during incubation. ${ }^{25}$

\section{Workflow}


Figure 2 shows the proposed workflow for the development of a continuous oscillatory flow protein crystallisation process, from screening to scale-ups in batch and continuous modes.

Stage I- Screening ( $\mu \mathrm{L}$ scale)

In order to develop the continuous crystallisation process for a target protein, it is important to know the crystallisation conditions. ${ }^{26-29}$ If they are not reported in literature, high-throughput screening experiments need to be performed, where protein crystallisation takes place in $\mu \mathrm{L}$ droplets under quiescent condition. The screening process typically starts with the vapour diffusion method, but it is also possible to start the microbatch method directly. ${ }^{10}$

The key crystallisation conditions include temperature, $\mathrm{pH}$, protein concentration and additive concentrations. $^{30}$ Extreme values of these variables should be avoided to minimise any potential irreversible denaturation of proteins. The efficiency of screening can be improved by the incomplete factorial and sparse matrix methods, which significantly reduces the number of screening conditions required for identifying the suitable conditions. ${ }^{31-33}$ Successful screening conditions can be used for constructing the protein phase diagram, where the precipitation and nucleation zone can be detected by the appearance of precipitate and crystal, while the growth zone can be detected by the microseed matrix screening method. ${ }^{34-38}$ The favourable crystallisation conditions can be further optimised to obtain crystals of desired morphology and size.

Stage II - transferring to batch process ( $\mathrm{mL}$ scale)

With the optimised crystallisation conditions from the screening step, the crystallisation can be first scaled up in a 1 mL tube, where mixing can be generated by shaking or stirring (magnetic stirrer). The mass transfer in the scaled-up experiments with mixing is significantly different from the quiescent screening experiments. Firstly, shear has been reported to accelerate the nucleation of proteins such as ferritin, apoferritin, lysozyme and insulin, ${ }^{3,39-41}$ as well as small organic molecules. ${ }^{23,42}$ On the other side, shear may narrow the metastable zone width ${ }^{24,43}$ and drive the crystallisation solution into the precipitation zone, ${ }^{6}$ where salt crystals formed or 
proteins are polymerized or denaturated. ${ }^{44}$ As scaling up to this small batch crystallisation, the concentrations can be tracked, and the size of crystals can be analyzed under microscope during the crystallisation process, which provide the initial information of the kinetics for the process design. Once one batch experiment is successful, the crystallisation conditions such as the shaking frequency or the stirring rate, as well as temperature, $\mathrm{pH}$ and protein concentrations can be optimised to desired targets of induction time and residence time.

Stage III - transferring to semi-continuous process ( $\mathrm{mL}$ scale)

The optimised shaking batch experiments can then be transferred to the oscillatory flow set-up that has a small volume of $2-3 \mathrm{~mL}$. Some large-scale protein crystallisation have been performed in stirred tank crystallisers due to their ease of control and operation, ${ }^{17,19,45-47}$ but tubular crystallisers have attracted the attention of researchers in recent years, due to the ability to achieve homogeneous mixing and hence narrower crystal size distribution in these crystallisers. 3,48,49,50 Tubular crystallisers can be operated in direct or oscillatory flow. In the first case, mixing can be enhanced by increasing the flow velocity or by introducing bubbles, ${ }^{39,40}$ but it might not be suitable for proteins that are sensitive to shear stress and exposure to gas. ${ }^{3}$ The oscillatory flow configuration avoids the problems of its direct flow counterpart as mixing is generated by the periodic change of flow direction and a lower flow velocity can be used. 3,24

The extent of shaking is useful for determining the frequency of oscillation with reference to the Reynold's number. The batch oscillatory flow crystallisation experiments can provide more accurate kinetics of the nucleation and crystallisation parameters for the process control of the continuous crystallisation. There are other factors that can be considered to improve the protein crystallisation, such as seeding, ${ }^{19}$ surface chemistry, ${ }^{51}$ and porous templates ${ }^{52}$ which have been reported for lysozyme, thaumatin, trypsin, catalase, concanavalin A and ferritin. ${ }^{4,52-}$ ${ }^{54}$ All these factors, as well as baffled oscillatory crystalliser, ${ }^{20,23}$ can be optimised at this stage for the introduction of a more efficient crystallisation process, prior to scaling up to the COFC. 


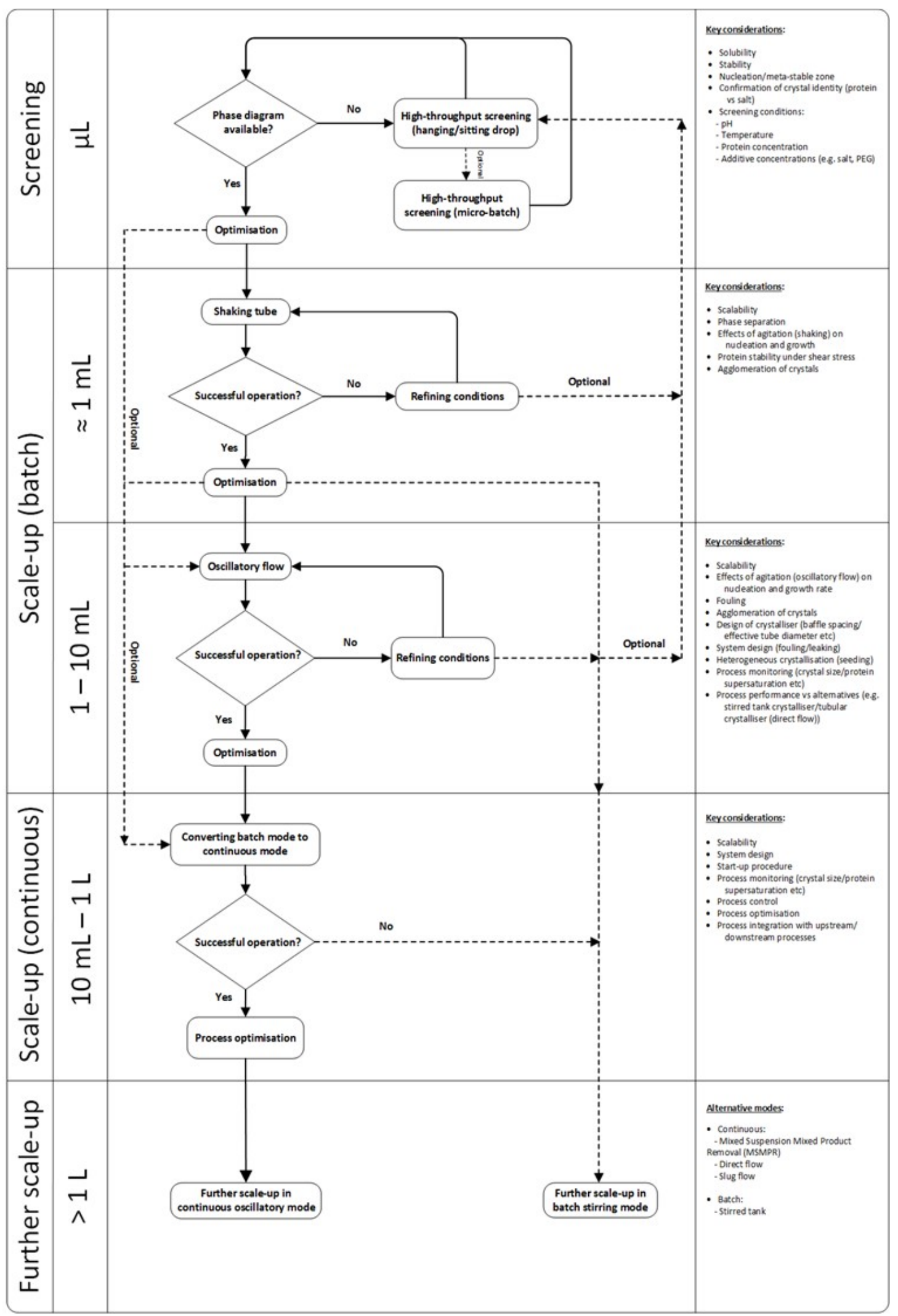

Figure 2 Workflow for the development of continuous oscillatory protein crystallisation. 
Stage IV - transferring to continuous process ( $\mathrm{mL}-\mathrm{L}$ scale)

In an oscillatory flow system, the continuous operation involves the continuous introduction of protein and precipitant into the system and the continuous removal of slurry through the outlet. The final step is to demonstrate the continuous crystallisation, which requires long time running. The transfer from the semi-continuous crystallisation to the continuous process may be robust at the initial continuous process, due to the similarity of the mixing conditions. However, the risks may dramatically increase due to long time running. Many challenges have been reported in previous developments of small organic molecules, ${ }^{20,55,56}$ such as leaking and fouling due to the long time running time. As in protein crystallisation, the residence time (slow growth rate $)^{57}$ and secondary nucleation (protein crystal is more fragile) ${ }^{44}$ are also challenges. The temperature changes along the oscillatory flow can be optimised, and the strategy of adding seeding or templates along the flow need to be considered.

\section{Results and discussions}

Batch shaking crystallisation

The target was to achieve a three-hour residence time, with a sufficient reduction in concentration to achieve an efficient yield. Based on the previous literatures of lysozyme crystallisation for buffer, $\mathrm{pH}$ and precipitant, ${ }^{24,40,58,59}$ two different initial concentrations; 50 and $90 \mathrm{mg} / \mathrm{mL}$, with three stirring rates, 100, 150 and $200 \mathrm{rpm}$ were investigated in BSC. Figure 3 show that the concentrations dropped to a relative low level during the first 180 min under these experimental conditions.

The crystallisation solutions in BSC with $90 \mathrm{mg} / \mathrm{mL}$ lysozyme solution all nucleated within 30 min, while the nucleation with $50 \mathrm{mg} / \mathrm{mL}$ lysozyme solution occurred at about 30 - 60 min with all three shaking rates, shown in Figure 3. At 120-180 min, the crystallisation solutions with 90 $\mathrm{mg} / \mathrm{mL}$ lysozyme solution were overall lower than those with $50 \mathrm{mg} / \mathrm{mL}$ lysozyme solution. The lysozyme concentration of crystallisation solution at 180 min indicated that the with $50 \mathrm{mg} / \mathrm{mL}$ 
lysozyme solution needed a longer time to reach equilibrium state than those with $90 \mathrm{mg} / \mathrm{mL}$ lysozyme solution.

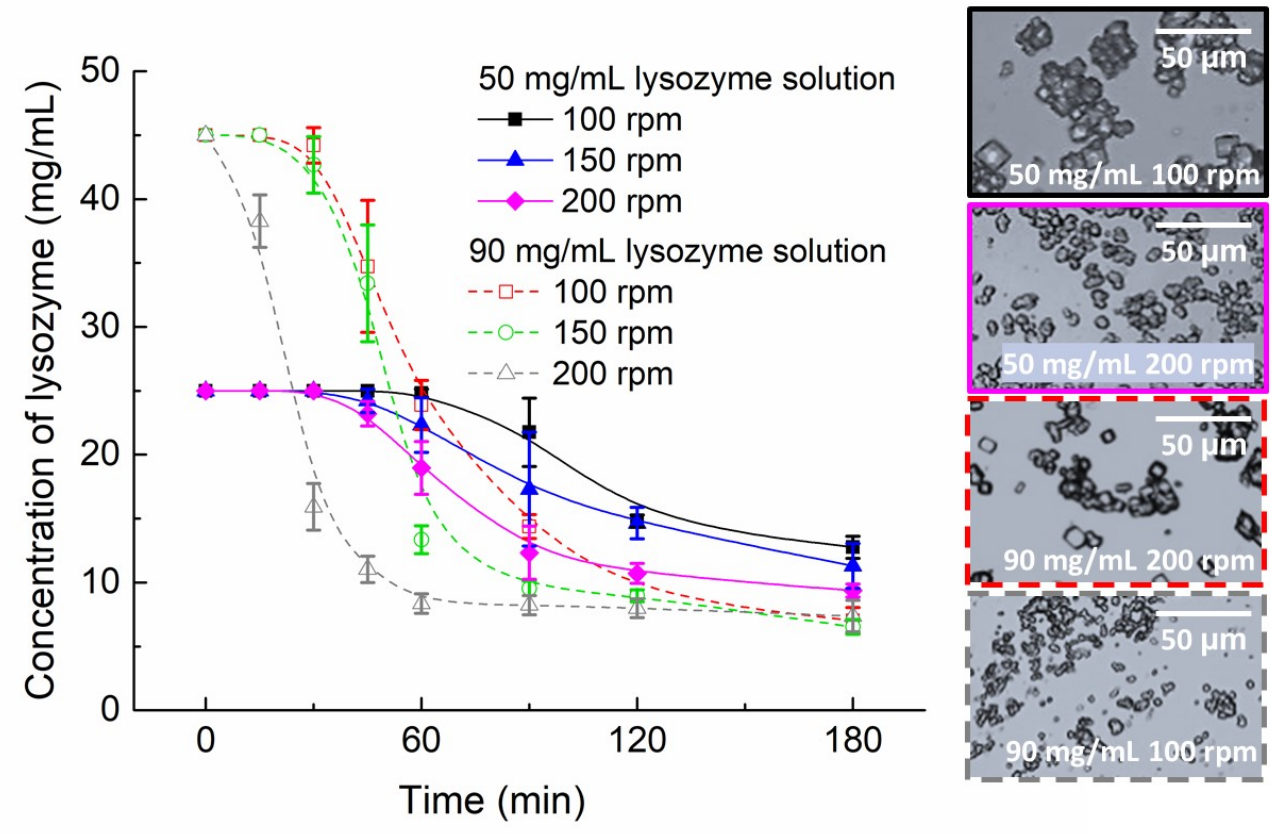

Figure 3 Lysozyme concentrations of crystallisation solutions after mixing in BSC with shaking rate of 100, 150 and $200 \mathrm{rpm}$, with initial lysozyme solutions at $50 \mathrm{mg} / \mathrm{mL}$ (shaking at 100 and $200 \mathrm{rpm}$ ) and $90 \mathrm{mg} / \mathrm{mL}$ (shaking at 100 and $200 \mathrm{rpm}$ ).

Crystal images in Figure 3 show that the crystals obtained from the high concentration lysozyme solutions were smaller than those from the low concentration lysozyme solution, indicating a higher nucleation rate and hence a larger number of crystals generated. Crystallisation solutions with $50 \mathrm{mg} / \mathrm{mL}$ lysozyme solution nucleated at about 100 min with the shaking rate of $100 \mathrm{rpm}$, while at about $30 \mathrm{~min}$ with shaking rate at $200 \mathrm{rpm}$. The faster the shaking rate was, the faster the decrease in concentration of crystallisation solution and smaller crystals were obtained (Figure 3) for lysozyme solutions of the same concentration. This could be a result of the higher homogeneous nucleation rate or secondary nucleation rate due to a higher shear rate, which is in consistence with the literatures. ${ }^{23,60}$ The crystals with the best shape were obtained in the lysozyme solution of low concentration $50 \mathrm{mg} / \mathrm{mL}$ with the low 
shaking rate at $100 \mathrm{rpm}$ in BSC (Figure 3). The higher shaking rates or higher concentrations resulted in smaller crystals, which indicated the number of crystals would be higher, and the edge of crystals became not obvious, i.e. irregular shape of the crystals.

Reynolds number, $R_{e}$, is used for defining the platforms and this parameter is used to transfer conditions from the BSC to the BOFC. For the shaking flasks/bioreactor and the oscillation crystalliser, $R_{e}$ [shaking] and $R_{e}$ [oscillation] can be estimated by Eqn. $1^{61,62}$ and Eqn. 2,20,63,64 respectively,

$$
\begin{aligned}
\left.R_{e} \text { [shaking }\right] & =\frac{n \rho d_{S H C}^{2}}{\mu} \\
\left.R_{e} \text { oscillation }\right] & =\frac{2 \pi f x_{0} \rho d_{O F C}}{\mu}
\end{aligned}
$$

where $\rho$ is the density of the liquid, which is assumed to be same as the water. $n$ is the shaking frequency with unit of $\mathrm{Hz}, d_{S H C}$ and $d_{O F C}$ are the inner-diameter of the shaking tube and oscillatory flow tube, respectively, and $\mu$ is dynamic fluid viscosity with unit of $\mathrm{mPa} / \mathrm{s}$.

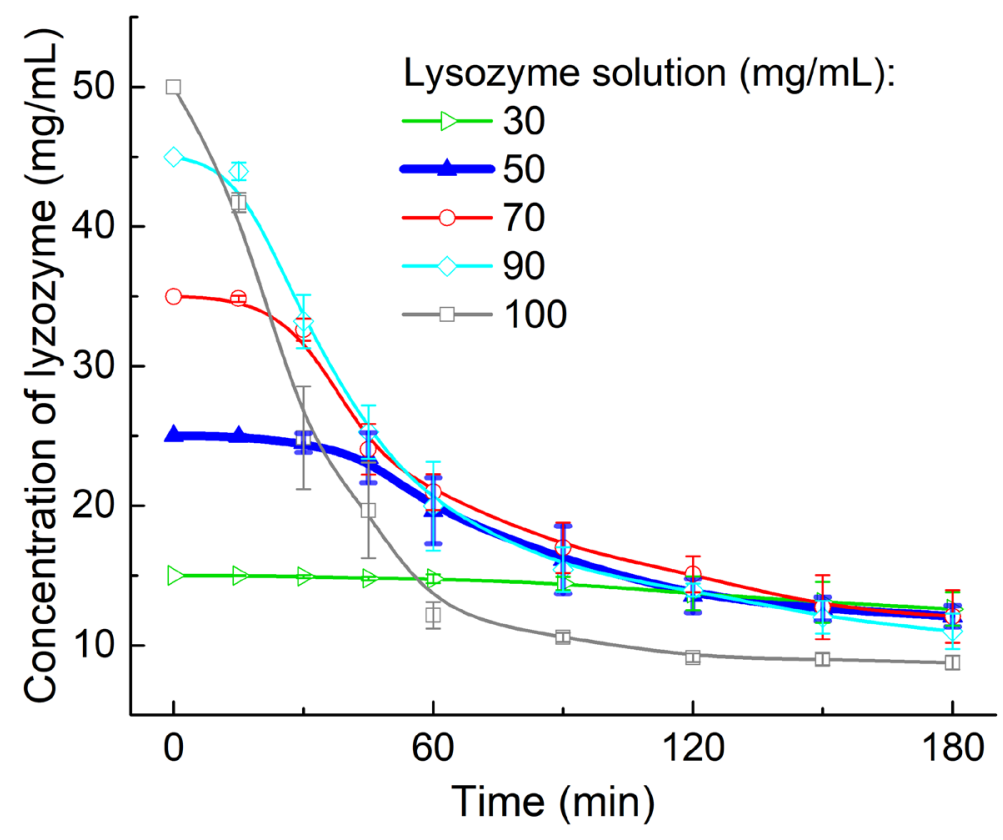

Figure 4 Lysozyme concentration for BOFC with $x_{0}$ at $20 \mathrm{~mm}$ and $f$ at $0.5 \mathrm{~Hz}$. Initial concentration of lysozyme solution was $30,50,70,90$ and $100 \mathrm{mg} / \mathrm{mL}$. 
The $R_{e}$ under different experimental conditions of BSC and BOFC are shown in Table 1. Based on the crystal shapes and the concentration profiles in BSC, the $50 \mathrm{mg} / \mathrm{mL}$ lysozyme solution with shaking rate of 150 - $200 \mathrm{rpm}$ were suitable experimental conditions for the process to transfer to BOFC. In this work, to further understand the influence of the oscillatory flow and concentration on the crystallisation of lysozyme, a larger range of shear rates (42-424 s-1) and concentrations $(30-100 \mathrm{mg} / \mathrm{mL})$ of lysozyme solution were investigated in BOFC.

\section{Batch oscillatory flow crystallisation}

The concentration of the crystallisation solution, shown in Figure 4, at 180 min with high concentration of lysozyme solution were lower than those with low concentration of lysozyme solution, which were in agreement with the BSC experimental results, indicating that the crystal growth was relatively slow and highly dependent on the particle number after the nucleation. The best shaped lysozyme crystal was obtained at $50 \mathrm{mg} / \mathrm{mL}$ in BOFC, and higher lysozyme concentrations resulted in poor quality of the crystals as excepted from the results in BSC.

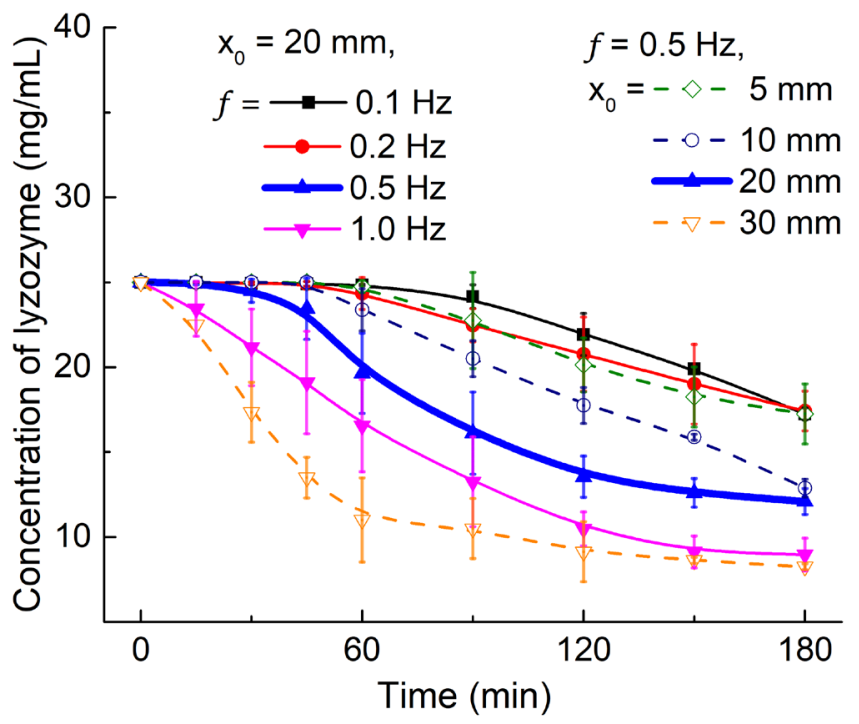

Figure 5: Lysozyme concentrations for BOFC with $x_{0}$ from 5 to $30 \mathrm{~mm}$ and $f$ from 0.1 to $1.0 \mathrm{~Hz}$. Initial concentration of lysozyme solution was $50 \mathrm{mg} / \mathrm{mL}$. 
The concentration of crystallisation solution in BOFC decreased faster with an increase in amplitude or frequency for the same frequency or amplitude, respectively. There was a noticeable extent of variations of concentration profiles in BOFC, though no obvious trends of the variations among different oscillatory conditions were found. It should be noted that the variations seemed to be slightly higher at very weak and very intensive oscillatory conditions. Based on the experimental results of crystal quality and the concentration profiles in Figure 4 and Figure 5, the $50 \mathrm{mg} / \mathrm{mL}$ lysozyme solution with $x_{0}$ at $10 \mathrm{~mm}$ and $f$ at $0.5 \mathrm{~Hz}$ was found to be a suitable experimental condition to achieve the target continuous process with a $180 \mathrm{~min}$ residence time.

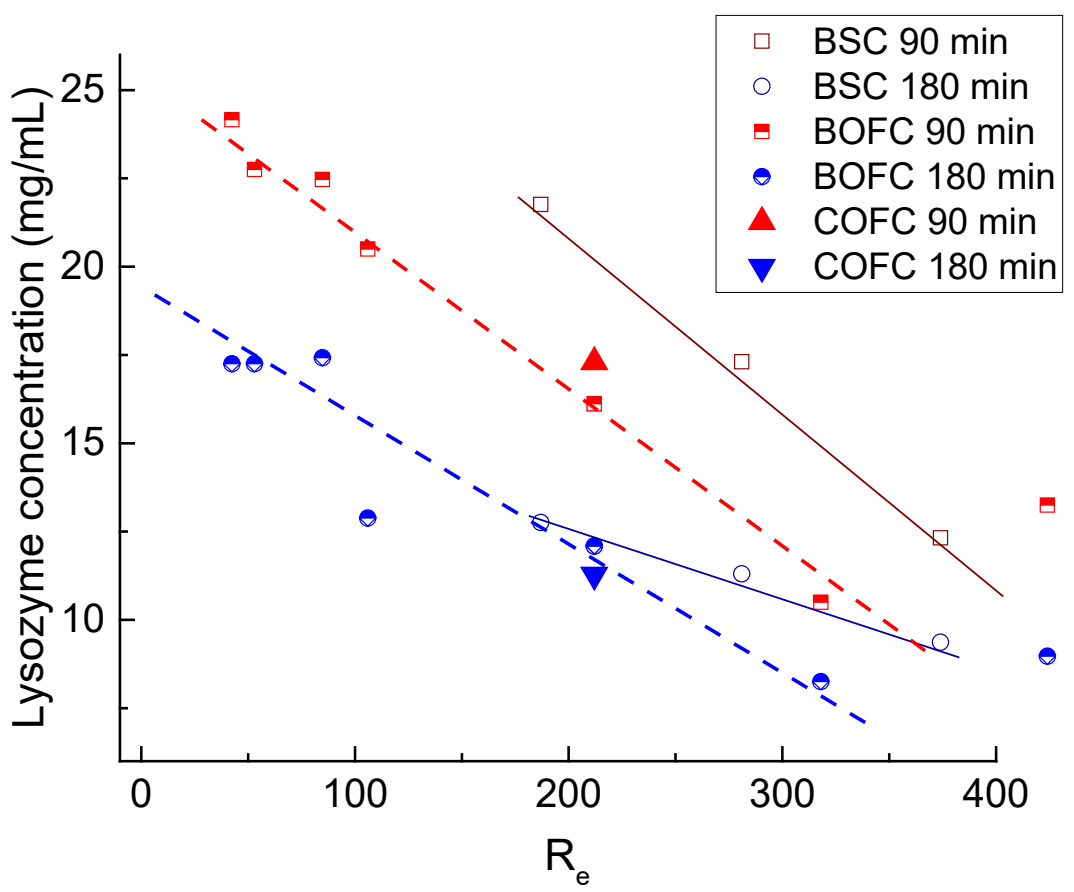

Figure 6 Average lysozyme concentrations for initial lysozyme solution of $50 \mathrm{mg} / \mathrm{mL}$ at different mixing conditions (hence different $R_{\mathrm{e}}$ ) with crystallisation time (in BSC and BOFC) / resident time (in COFC) of 90 and $180 \mathrm{~min}$. The straight solid and dashed lines are guiding lines for BSC and BOFC, respectively. 


\section{Continuous oscillatory flow crystallisation}

The net flow rate (Q) $0.1 \mathrm{~mL} / \mathrm{min}$ was applied in the COFC, for a tube with four sample points, i.e. the mixing point and around 1, 2 and $3 \mathrm{~m}$ from the mixing point, with the optimised experimental condition from the $\mathrm{COBC}$ studies. The residence time of the lysozyme crystallisation solution in the COFC was 180 min by the designed $\mathrm{Q}$, and, correspondingly, the solution taken from these four sample points had 0,60, 120 and 180 min residence time, respectively, shown in Figure 7. As excepted, the lysozyme concentrations of the crystallisation solution was constant at the mixing point. The concentration of the crystallisation solution at 60 min from the sample point two, $120 \mathrm{~min}$ from sample point 3 and $180 \mathrm{~min}$ from sample point 4 in the COFC were consistent with the concentrations in BOFC (Figure 6) at respective residence time, demonstrating a successful process transfer from BOFC to COFC. These results were consistent with the literature on the nucleation of butyl paraben in batch and continuous OFC. $^{23}$

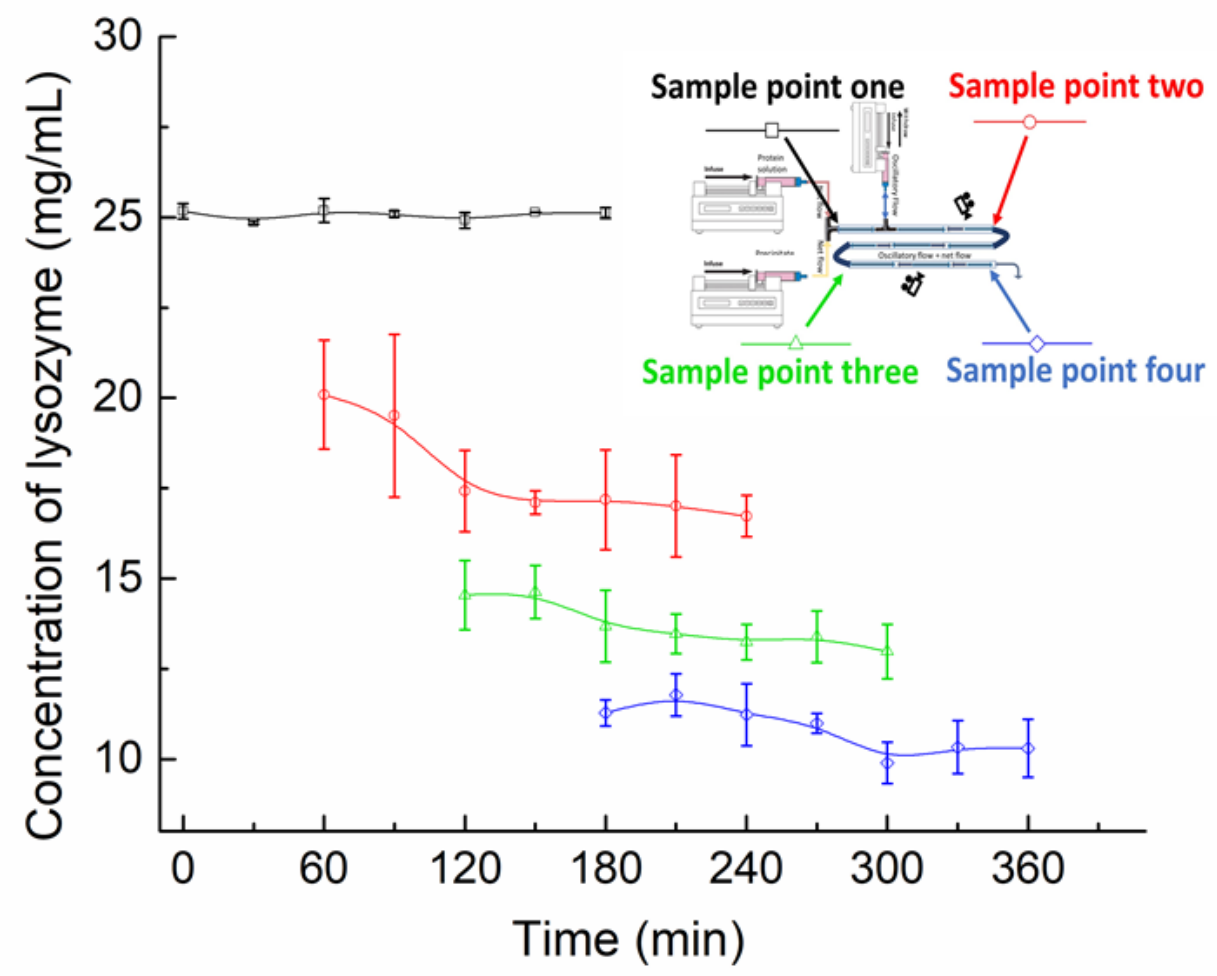

Figure 7 Lysozyme concentration at four sample points $(0,1,2$ and $3 \mathrm{~m}$ to the mixing point) for the COFC. 
Figure 7 shows the longer the residence time of the crystallisation solution, the lower the concentration became and larger crystals were obtained. There were no crystals observed at the sample point one, and the crystals obtained from the last three sample points all had good crystal shapes. The size distributions were mainly normal distributions with a tiny peak at around $1 \mu \mathrm{m}$. The size distribution of crystals obtained from 180 - $270 \mathrm{~min}$ is very similar to those crystals from 270 - 360 min, while the later crystals were on average slightly larger with fewer fine particles, due to the lower concentration and longer growth time for the crystals at later stages. The similar size distributions with an average particle size of $11-12 \mu \mathrm{m}$ and the concentrations indicate the steady state of the continuous crystallisation at each sample point after $180 \mathrm{~min}$ in COFC.

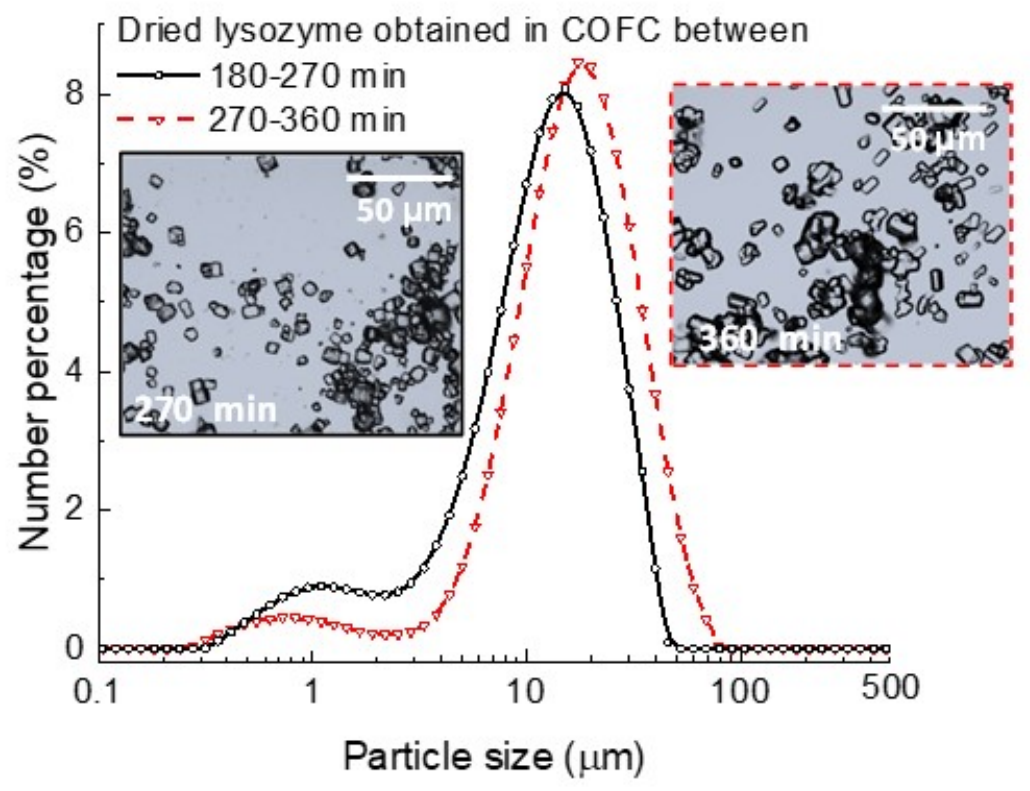

Figure 8 Size distributions of lysozyme crystals obtained in the COFC and lysozyme crystal images in the sample solution from sample point three at 300 and $360 \mathrm{~min}$, respectively, during the experiment.

In Figure 9, a steeper slope corresponds to faster micrococcus lysodeikticus cells lysis and higher bioactivity of lysozyme per units volume solution. ${ }^{50}$ By using the same micrococcus lysodeikticus cells solution, the activity determination results show the activity of lysozyme 
obtained from continuous oscillatory crystallisation was $20 \%$ higher than the activity of the raw lysozyme materials, indicating the higher purity of lysozyme than the raw materials. This is an improvement in the quality of lysozyme as compared to the as-received material which was freeze-dried.

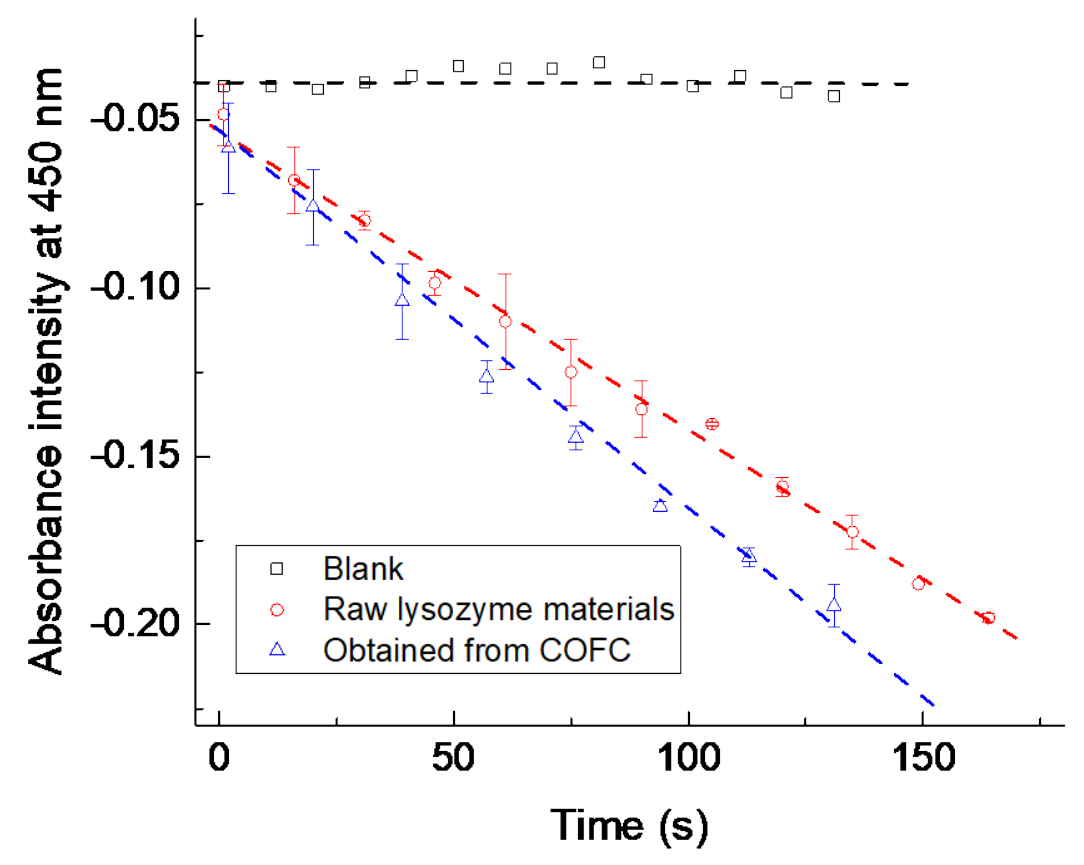

Figure 9 Absorbance intensity at $450 \mathrm{~nm}$ of micrococcus lysodeikticus cells solution. Adding only buffer solution without lysozyme (rectangle symbol with black color), lysozyme of raw materials (round symbol with red color) and lysozyme obtained in COFC (triangle symbol with blue color) in buffer solution.

\section{Discussions}

In this work, we focused on the development from Stage II to Stage IV utilising lysozyme as a model protein, due to the numerous studies reported for its crystallisation conditions in hanging drop experiments, ${ }^{24,40,58,59,65}$ and the availability of phase diagrams, ${ }^{24,58}$ bypassing Stage 1. For other target proteins, however, the suitable crystallisation conditions may be unavailable and not easy to predict, ${ }^{6}$ i.e. it is still challenges to obtain single crystals of $\mu \mathrm{m}$ size for the structural determination of the target protein. ${ }^{66}$ In some cases, the suitable crystallisation 
condition, which leads to a very slow crystallisation process (more than weeks), may greatly hinder the development at Stage II.

The higher concentrations and higher share rate reduce the induction time and accelerate the crystallisation process, but it may lead to the formation of small crystals as shown in Figure 3, and induce different morphology as needle shape lysozyme reported, ${ }^{24}$ in agreement with the literature. ${ }^{40,67,68,69}$ It is preferable to test additional experimental conditions to determine kinetic parameters, at this stage, due to the ease of operations for the small volume tubes compared to the oscillatory flow crystalliser ${ }^{69}$ or other semi-continuous platforms. ${ }^{24}$ There were three periods of the changing concentration. ${ }^{69}$ As an example, for the crystallisation process with a shaking rate of $100 \mathrm{rpm}$, the conditions are: (A) an induction period (no decrease in concentration before nucleation), (B) a rapid concentration drop period, i.e. nucleation (homogeneous and secondary) and fast crystal growth at high supersaturation level and (C) a slow concentration decrease period, i.e. crystal growth at low supersaturation level. However, at very high concentration and high shaking rate, the A-period diminishes, and at low concentration with low shaking rate, the C-period was not clearly established during a period of 180 minutes. Comparing with the crystallisation processes of many small-molecule ${ }^{70,71}$ with a sharp fall of the concentration after nucleation, the concentration decrease in many protein crystallisation is relative slow after nucleation ${ }^{17,39}$ due to high packing energy, low attachment frequency and slow kinetics of growth and etc. ${ }^{51}$ These periods influence the size distribution of the final crystal products by different mechanisms, like secondary nucleation or crystal growth, the mechanisms combined with simulations and process modelling need to be further investigated.

The nucleation behaviour is also crucial in order to develop an understanding of the protein crystallisation process. The nucleation occurring was estimated by the sampling time when the average concentration reduced by $2 \%$ from the initial lysozyme concentration in crystallisation solution. The increase in the flow velocity of the solution generated by the syringes ${ }^{69}$, i.e. $4 x_{0} f$, decreases the nucleation time as shown in Figure 10, for a crystallisation solution of the same 
supersaturation. The shear, increasing with increase of velocity, accelerated the nucleation rate of lysozyme, which is consistent with the crystallisation of other proteins. ${ }^{3}$ Additionally, the control of the nucleation step with seeds or nano-templates is currently being investigated,,$^{52}$ in batch modes which can be useful for transfer to Stage IV.

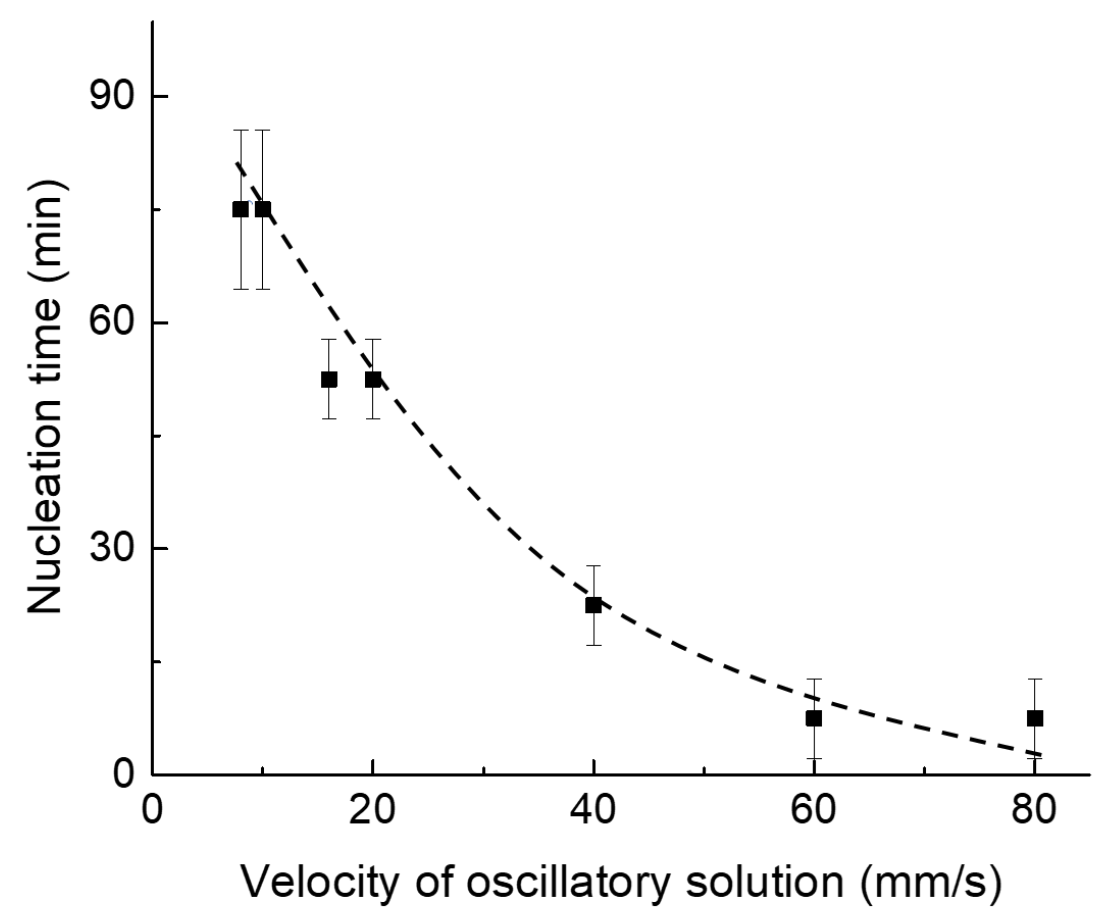

Figure 10 The average nucleation time of lysozyme solutions for the same oscillatory velocity of the solution in BOFC. Dashed line is a guiding line.

In development stage IV, limited fouling in the oscillatory flow tube was observed along the tubing. It is heavier at the location near the mixing point where the supersaturation was significantly higher than further downstream locations. However, there was no blockage at the mixing point, due to the slow nucleation and crystal growth rate. There was no leaking and blockage in this work during the whole process. A drop of concentration at each sample point was observed after the initial crystallisation solution flow reached. This is because some lysozyme crystals formed after 30-60 min were trapped in the oscillatory flow between the oscillatory syringe and the net flow tube, which acted as seeds to the continuous oscillatory 
flow solution in the crystallisation process. The seeding effect induced the concentration drop which was lower than the concentrations in respective residence time in the BOFC, and the concentrations reached an equilibrium after $180 \mathrm{~min}$ in these sample points. The trapped crystals, without resulting in blockage and leaking, may indicate the indicate the robustness of continuous crystallisation developed.

The crystals obtained have limited agglomeration. The agglomerates break down after a very short sonication time, shown in the supporting information section. The yield in this COFC is $60 \%$, as estimated from the concentration determined at beginning $(25 \mathrm{mg} / \mathrm{mL})$ and the end of the crystallisation process $(10 \mathrm{mg} / \mathrm{mL})$. This yield is similar to the one reported in literature, where $68 \%$ of dissolved lysozyme was crystallised under slug flow with a resident time of 113 minutes. ${ }^{39}$ Correspondingly, the space time yield is above $3.8 \mathrm{~g} / \mathrm{Lh}$. The yield can be improved by increasing the concentration of protein and precipitant, the residence time or the share rate, and can be further improved by decreasing the temperature. ${ }^{3,58}$ Varying process conditions and operating parameters can lead to an optimised continuous crystallisation process, whilst ensuring that the final crystal product meets quality, purity and bioactivity requirements.

\section{Conclusions}

In this work, we applied a basic workflow for the development of continuous oscillatory crystallisation process for a model protein, lysozyme from batch crystallisation. Four efficient steps to develop a continuous oscillatory flow crystallisation: 1). hanging-drop screening offers the suitable buffer, precipitant, $\mathrm{pH}$ and etc; 2). shaking batch crystallisation provides insight into basic kinetics and thermodynamics of the crystallisation; 3). batch oscillatory flow crystallisation offers more precise control of the protein concentration and mixing condition in the oscillatory flow; 4). continuous oscillatory flow crystallisation is finally established and further optimized, are reported. The higher concentration of lysozyme solution and higher frequency and amplitude in oscillatory flow enhanced the nucleation and crystallisation, leading to a reduction in the particle size and an increase in the number of the crystals. In the continuous oscillatory flow crystallisation, the concentration decreased with an increase in 
residence time and steady stage was achieved. The lysozyme crystals obtained in this continuous crystallisation platform has a consistent size distribution. The lysozyme crystals obtained from this continuous oscillatory flow crystallization platform has both a good crystal shape and high bioactivity.

\section{Notations}

$\begin{array}{llr}C & \text { Concentration of lysozyme solution } & (\mathrm{mg} / \mathrm{mL}) \\ d_{\mathrm{OFC}} & \text { Diameter of shaking tube } & (\mathrm{m}) \\ d_{\mathrm{SHC}} & \text { Diameter of oscillatory flow tube } & (\mathrm{m}) \\ f & \text { Frequency of oscillatory flow } & (\mathrm{Hz}) \\ n & \text { Shaking frequency } & (1 / \mathrm{s}) \\ Q & \text { Net flow rate } & (\mathrm{mL} / \mathrm{min}) \\ R_{e} & \text { Reynold's number } & \\ R_{e}[\text { shaking] } & \text { Reynold's number in shaking tube } & \\ R_{e}[\text { oscillation }] & \text { Reynold's number in oscillatory flow } & (\mathrm{mm}) \\ x_{0} & \text { Amplitude of oscillatory flow } & (\mathrm{kg} / \mathrm{m}) \\ \rho & \text { Liquid density } & (\mathrm{rpm}) \\ \pi & \text { 3.1416 } & (\mathrm{mPa} . \mathrm{s}) \\ \omega & \text { Shaking rate } & \end{array}$

\section{Acknowledgements}

We acknowledge the EPSRC (EP/N015916/1) for funding.

\section{References}

(1) Morrison, C. Fresh from the Biotech Pipeline-2016. Nat. Biotechnol. 2017, 35, 108-112.

(2) Basu, S. K.; Govardhan, C. P.; Jung, C. W.; Margolin, A. L. Protein Crystals for the Delivery of Biopharmaceuticals. Expert Opin. Biol. Ther. 2004, 4, 301-317.

(3) Parambil, J. V.; Schaepertoens, M.; Williams, D. R.; Heng, J. Y. Y. Effects of Oscillatory Flow on the Nucleation and Crystallization of Insulin. Cryst. Growth Des. 2011, 11, 4353-4359. 
(4) Delmas, T.; Roberts, M. M.; Heng, J. Y. Y. Nucleation and Crystallization of Lysozyme: Role of Substrate Surface Chemistry and Topography. J. Adhes. Sci. Technol. 2011, 25, 357-366.

(5) Harrison, R. G.; Todd, P.; Rudge, S. R.; Petrides, D. P. Bioseparations Science and Engineering. Topics in Chemical Engineering. 2015.

(6) Chayen, N. E.; Saridakis, E. Protein Crystallization: From Purified Protein to DiffractionQuality Crystal. Nat. Methods 2008, 5, 147-153.

(7) Usón, I.; Sheldrick, G. M. Advances in Direct Methods for Protein Crystallography. Curr. Opin. Struct. Biol. 1999, 9, 643-648.

(8) Stevens, R. C. High-Throughput Protein Crystallization. Curr. Opin. Struct. Biol. 2000, 10, 558-563.

(9) Zang, Y.; Kammerer, B.; Eisenkolb, M.; Lohr, K.; Kiefer, H. Towards Protein Crystallization as a Process Step in Downstream Processing of Therapeutic Antibodies: Screening and Optimization at Microbatch Scale. PLoS One. 2011, 6.

(10) Chayen, N. E.; Shaw Stewart, P. D.; Maeder, D. L.; Blow, D. M. An Automated System for Micro-Batch Protein Crystallization and Screening. J. Appl. Crystallogr. 1990, 23, 297-302.

(11) Carpenter, E. P.; Beis, K.; Cameron, A.D.; Iwata, S. Overcoming the Challenges of Membrane Protein Crystallography. Curr. Opin. Struct. Biol. 2008, 18, 581-586.

(12) Chen, R. Q.; Cheng, Q. Di; Chen, J. J.; Sun, D. S.; Ao, L. B.; Li, D. W.; Lu, Q. Q.; Yin, D. C. An Investigation of the Effects of Varying PH on Protein Crystallization Screening. CrystEngComm 2017, 19, 860-867.

(13) McPherson, A. Introduction to Protein Crystallization. Methods. 2004, 34, 254-265.

(14) McPherson, A. Crystallization of Proteins from Polyethylene Glycol. J. Biol. Chem. 1976, $251,6300-6303$.

(15) Hou, D.; Chang, H.-C. Ac Field Enhanced Protein Crystallization. Appl. Phys. Lett. 2008, 92, 223902.

(16) Hebel, D.; Ürdingen, M.; Hekmat, D.; Weuster-Botz, D. Development and Scale up of High-Yield Crystallization Processes of Lysozyme and Lipase Using Additives. Cryst. Growth Des. $2013,13,2499-2506$. 
(17) Hebel, D.; Huber, S.; Stanislawski, B.; Hekmat, D. Stirred Batch Crystallization of a Therapeutic Antibody Fragment. J. Biotechnol. 2013, 166, 206-211.

(18) Hekmat, D.; Huber, M.; Lohse, C.; Von Den Eichen, N.; Weuster-Botz, D. Continuous Crystallization of Proteins in a Stirred Classified Product Removal Tank with a Tubular Reactor in Bypass. Cryst. Growth Des. 2017, 17, 4162-4169.

(19) Judge, R. A.; Johns, M. R.; White, E. T. Protein Purification by Bulk Crystallization: The Recovery of Ovalbumin. Biotechnol. Bioeng. 1995, 48, 316-323.

(20) McGlone, T.; Briggs, N. E. B.; Clark, C. A.; Brown, C. J.; Sefcik, J.; Florence, A. J. Oscillatory Flow Reactors (OFRs) for Continuous Manufacturing and Crystallization. Org. Process Res. Dev. 2015, 1186-1202.

(21) Baxendale, I. R.; Braatz, R. D.; Hodnett, B. K.; Jensen, K. F.; Johnson, M. D.; Sharratt, P.; Sherlock, J. P.; Florence, A. J. Achieving Continuous Manufacturing: Technologies and Approaches for Synthesis, Workup, and Isolation of Drug Substance May 20-21, 2014 Continuous Manufacturing Symposium. J. Pharm. Sci. 2015, 104, 781-791.

(22) Su, Q.; Nagy, Z. K.; Rielly, C. D. Pharmaceutical Crystallisation Processes from Batch to Continuous Operation Using MSMPR Stages: Modelling, Design, and Control. Chem. Eng. Process. Process Intensif. 2015, 89, 41-53.

(23) Yang, H.; Yu, X.; Raval, V.; Makkawi, Y.; Florence, A. Effect of Oscillatory Flow on Nucleation Kinetics of Butyl Paraben. Cryst. Growth Des. 2016, 16, 875-886.

(24) Castro, F.; Ferreira, A.; Teixeira, J. A.; Rocha, F. Protein Crystallization As a Process Step in a Novel Meso Oscillatory Flow Reactor: Study of Lysozyme Phase Behavior. Cryst. Growth Des. 2016, 16, 3748-3755.

(25) Wang, T.; Riegger, A.; Lamla, M.; Wiese, S.; Oeckl, P.; Otto, M.; Wu, Y.; Fischer, S.; Barth, H.; Kuan, S. L.; Weil, T. Water-Soluble Allyl Sulfones for Dual Site-Specific Labelling of Proteins and Cyclic Peptides. Chem. Sci. 2016, 7, 3234-3239.

(26) Weselak, M.; Patch, M. G.; Selby, T. L.; Knebel, G.; Stevens, R. C. Robotics for Automated Crystal Formation and Analysis. Methods Enzymol. 2003, 368, 45-76. 
(27) Morissette, S. L.; Almarsson, Ö.; Peterson, M. L.; Remenar, J. F.; Read, M. J.; Lemmo, A. V.; Ellis, S.; Cima, M. J.; Gardner, C. R. High-Throughput Crystallization: Polymorphs, Salts, CoCrystals and Solvates of Pharmaceutical Solids. Adv. Drug Deliv. Rev. 2004, 275-300.

(28) McRee, D. E. Practical Protein Crystallography. Academic press. 1999.

(29) Jaskolski, M.; Dauter, Z.; Wlodawer, A. A Brief History of Macromolecular Crystallography, Illustrated by a Family Tree and Its Nobel Fruits. FEBS Journal. 2014, 39854009.

(30) Hekmat, D. Large-Scale Crystallization of Proteins for Purification and Formulation. Bioprocess Biosyst. Eng. 2015, 38, 1209-1231.

(31) Carter, C. W.; Carter, C. W. Protein Crystallization Using Incomplete FactorialExperiments. J. Biol. Chem. 1979, 254, 2219-2223.

(32) Jancarik, J.; Kim, S. H. Sparse Matrix Sampling. A Screening Method for Crystallization of Proteins. J. Appl. Crystallogr. 1991, 24, 409-411.

(33) Cudney, R.; Patel, S.; Weisgraber, K.; Newhouse, Y.; McPherson, A. Screening and Optimization Strategies for Macromolecular Crystal Growth. Acta Crystallogr. Sect. D Biol. Crystallogr. 1994, 50, 414-423.

(34) Ireton, G. C.; Stoddard, B. L. Microseed Matrix Screening to Improve Crystals of Yeast Cytosine Deaminase. Acta Crystallogr. Sect. D Biol. Crystallogr. 2004, 60, 601-605.

(35) D’Arcy, A.; Villard, F.; Marsh, M. An Automated Microseed Matrix-Screening Method for Protein Crystallization. Acta Crystallogr. Sect. D Biol. Crystallogr. 2007, 63, 550-554.

(36) Abskharon, R. N. N.; Soror, S. H.; Pardon, E.; El Hassan, H.; Legname, G.; Steyaert, J.; Wohlkonig. A. Combining In-Situ Proteolysis and Microseed Matrix Screening to Promote Crystallization of PrPc-Nanobody Complexes. Protein Eng. Des. Sel. 2011, 24, 737-741.

(37) Malia, T. J.; Obmolova, G.; Luo, J.; Teplyakov, A.; Sweet, R.; Gilliland, G. L. Crystallization of a Challenging Antigen-Antibody Complex: TLR3 ECD with Three Noncompeting Fabs. Acta Crystallogr. Sect. F Struct. Biol. Cryst. Commun. 2011, 67, 1290-1295.

(38) Obmolova, G.; Malia, T. J.; Teplyakov, A.; Sweet, R. W.; Gilliland, G. L. Protein Crystallization with Microseed Matrix Screening: Application to Human Germline Antibody Fabs. Acta Crystallogr. Sect. FStructural Biol. Commun. 2014, 70, 1107-1115. 
(39) Neugebauer, P.; Khinast, J. G. Continuous Crystallization of Proteins in a Tubular PlugFlow Crystallizer. Cryst. Growth Des. 2015, 15, 1089-1095.

(40) Roberts, M. M.; Heng, J. Y. Y.; Williams, D. R. Protein Crystallization by Forced Flow through Glass Capillaries: Enhanced Lysozyme Crystal Growth. Cryst. Growth Des. 2010, 10, 1074-1083.

(41) Penkova, A.; Pan, W.; Hodjaoglu, F.; Vekilov, P. G. Nucleation of Protein Crystals under the Influence of Solution Shear Flow. Ann. N. Y. Acad. Sci. 2006, 1077, 214-231.

(42) Liu, J.; Rasmuson, Å. C. Influence of Agitation and Fluid Shear on Primary Nucleation in Solution. Cryst. Growth Des. 2013, 13, 4385-4394.

(43) Yang, H.; Florence, A. J. Relating Induction Time and Metastable Zone Width. CrystEngComm. 2017, 19, 3966-3978.

(44) Anderson, D. E.; Becktel, W. J.; Dahlquist, F. W. PH-Induced Denaturation of Proteins: A Single Salt Bridge Contributes 3-5 Kcal/Mol to the Free Energy of Folding of T4 Lysozyme. Biochemistry. 1990, 29, 2403-2408.

(45) Smejkal, B.; Agrawal, N. J.; Helk, B.; Schulz, H.; Giffard, M.; Mechelke, M.; Ortner, F.; Heckmeier, P.; Trout, B. L.; Hekmat, D. Fast and Scalable Purification of a Therapeutic FullLength Antibody Based on Process Crystallization. Biotechnol. Bioeng. 2013, 110, 2452-2461.

(46) Takakura, T.; Ito, T.; Yagi, S.; Notsu, Y.; Itakura, T.; Nakamura, T.; Inagaki, K.; Esaki, N.; Hoffman, R. M.; Takimoto, A. High-Level Expression and Bulk Crystallization of Recombinant LMethionine $y$-Lyase, an Anticancer Agent. Appl. Microbiol. Biotechnol. 2006, 70, 183-192.

(47) Peters, J.; Minuth, T.; Schröder, W. Implementation of a Crystallization Step into the Purification Process of a Recombinant Protein. Protein Expr. Purif. 2005, 39, 43-53.

(48) Womersley, J. R. Oscillatory Flow in Arteries: The Constrained Elastic Tube as a Model of Arterial Flow and Pulse Transmission. Phys. Med. Biol. 1957, 2, 178-187.

(49) Kadowaki, A.; Yoshizaki, I.; Rong, L.; Komatsu, H.; Odawara, O.; Yoda, S. Improvement of Protein Crystal Quality by Forced Flow Solution. J. Synchrotron Radiat. 2004, 11, 38-40.

(50) Vekilov, P. G.; Rosenberger, F. Protein Crystal Growth under Forced Solution Flow: Experimental Setup and General Response of Lysozyme. J. Cryst. Growth. 1998, 186, 251-261. 
(51) Derewenda, Z. S.; Vekilov, P. G. Entropy and Surface Engineering in Protein Crystallization. Acta Crystallographica Section D: Biological Crystallography. 2006, 62, 116-124.

(52) Shah, U. V.; Amberg, C.; Diao, Y.; Yang, Z.; Heng, J. Y. Y. Heterogeneous Nucleants for Crystallogenesis and Bioseparation. Curr. Opin. Chem. Eng. 2015, 8, 69-75.

(53) Barros Groß, M.; Kind, M. Comparative Study on Seeded and Unseeded Bulk Evaporative Batch Crystallization of Tetragonal Lysozyme. Cryst. Growth Des. 2017, 17, 3491-3501.

(54) Shah, U. V.; Williams, D. R.; Heng, J. Y. Y. Selective Crystallization of Proteins Using Engineered Nanonucleants. Cryst. Growth Des. 2012, 12, 1362-1369.

(55) Yang, X.; Acevedo, D.; Mohammad, A.; Pavurala, N.; Wu, H.; Brayton, A. L.; Shaw, R. A.; Goldman, M. J.; He, F.; Li, S.; Fisher, R. J.; O’Connor, T.F.; Cruz. C. N. Risk Considerations on Developing a Continuous Crystallization System for Carbamazepine. Org. Process Res. Dev. 2017, 21, 1021-1033.

(56) Powell, K. A.; Saleemi, A. N.; Rielly, C. D.; Nagy, Z. K. Monitoring Continuous Crystallization of Paracetamol in the Presence of an Additive Using an Integrated PAT Array and Multivariate Methods. Org. Process Res. Dev. 2016, 20, 626-636.

(57) Kam, Z.; Shore, H. B.; Feher, G. On the Crystallization of Proteins. J. Mol. Biol. 1978, 123, 539-555.

(58) Liu, Y.; Wang, X.; Ching, C. B. Toward Further Understanding of Lysozyme Crystallization: Phase Diagram, Protein-Protein Interaction, Nucleation Kinetics, and Growth Kinetics. Cryst. Growth Des. 2010, 10, 548-558.

(59) Durbin, S. D.; Feher, G. Crystal Growth Studies of Lysozyme as a Model for Protein Crystallization. J. Cryst. Growth. 1986, 76, 583-592.

(60) Ploß, R.; Mersmann, A. A New Model of the Effect of Stirring Intensity on the Rate of Secondary Nucleation. Chem. Eng. Technol. 1989, 12, 137-146.

(61) Peter, C. P.; Suzuki, Y.; Rachinskiy, K.; Lotter, S.; Büchs, J. Volumetric Power Consumption in Baffled Shake Flasks. Chem. Eng. Sci. 2006, 61, 3771-3779.

(62) Büchs, J.; Maier, U.; Milbradt, C.; Zoels, B. Power Consumption in Shaking Flasks on Rotary Shaking Machines: I. Power Consumption Measurement in Unbaffled Flasks at Low Liquid Viscosity. Biotechnol. Bioeng. 2000, 68, 589-593. 
(63) Sobey, I. J. Observation of Waves during Oscillatory Channel Flow. J. Fluid Mech. 1985, 151, 395-426.

(64) Ricardo, C.; Xiongwei, N. Evaluation and Establishment of a Cleaning Protocol for the Production of Vanisal Sodium and Aspirin Using a Continuous Oscillatory Baffled Reactor. Org. Process Res. Dev. 2009, 13, 1080-1087.

(65) Burke, M. W.; Judge, R. A.; Pusey, M. L. The Effect of Solution Thermal History on Chicken Egg White Lysozyme Nucleation. J. Cryst. Growth. 2001, 232, 301-307.

(66) Anderson, M. J.; Hansen, C. L.; Quake, S. R. Phase Knowledge Enables Rational Screens for Protein Crystallization. Proc. Natl. Acad. Sci. 2006, 103, 16746-16751.

(67) Blandin, A. F.; Mangin, D.; Rivoire, A.; Klein, J. P.; Bossoutrot, J. M. Agglomeration in Suspension of Salicylic Acid Fine Particles: Influence of Some Process Parameters on Kinetics and Agglomerate Final Size. Powder Technol. 2003, 130, 316-323.

(68) Spicer, P. T.; Pratsinis, S. E.; Raper, J.; Amal, R.; Bushell, G.; Meesters, G. Effect of Shear Schedule on Particle Size, Density, and Structure during Flocculation in Stirred Tanks. Powder Technol. 1998, 97, 26-34.

(69) Yang, H.; Peczulis, P.; Inguva, P.; Li, X.; Heng, J. Y. Y. Continuous Protein Crystallisation Platform and Process: Case of Lysozyme. Chem. Eng. Res. Des. 2018,136, 529-535.

(70) Mullin, J. W. Crystallization. Elsevier. 2001.

(71) Yang, H.; Rasmuson, Å. C. Investigation of Batch Cooling Crystallization in a Liquid-Liquid Separating System by PAT. Org. Process Res. Dev. 2012, 16, 1212-1224. 


\section{For Table of Contents Use Only}

The development and workflow of a continuous protein crystallisation process: A case of lysozyme

Huaiyu Yang, Wenqian Chen, Peter Peczulis, and Jerry Y. Y. Heng

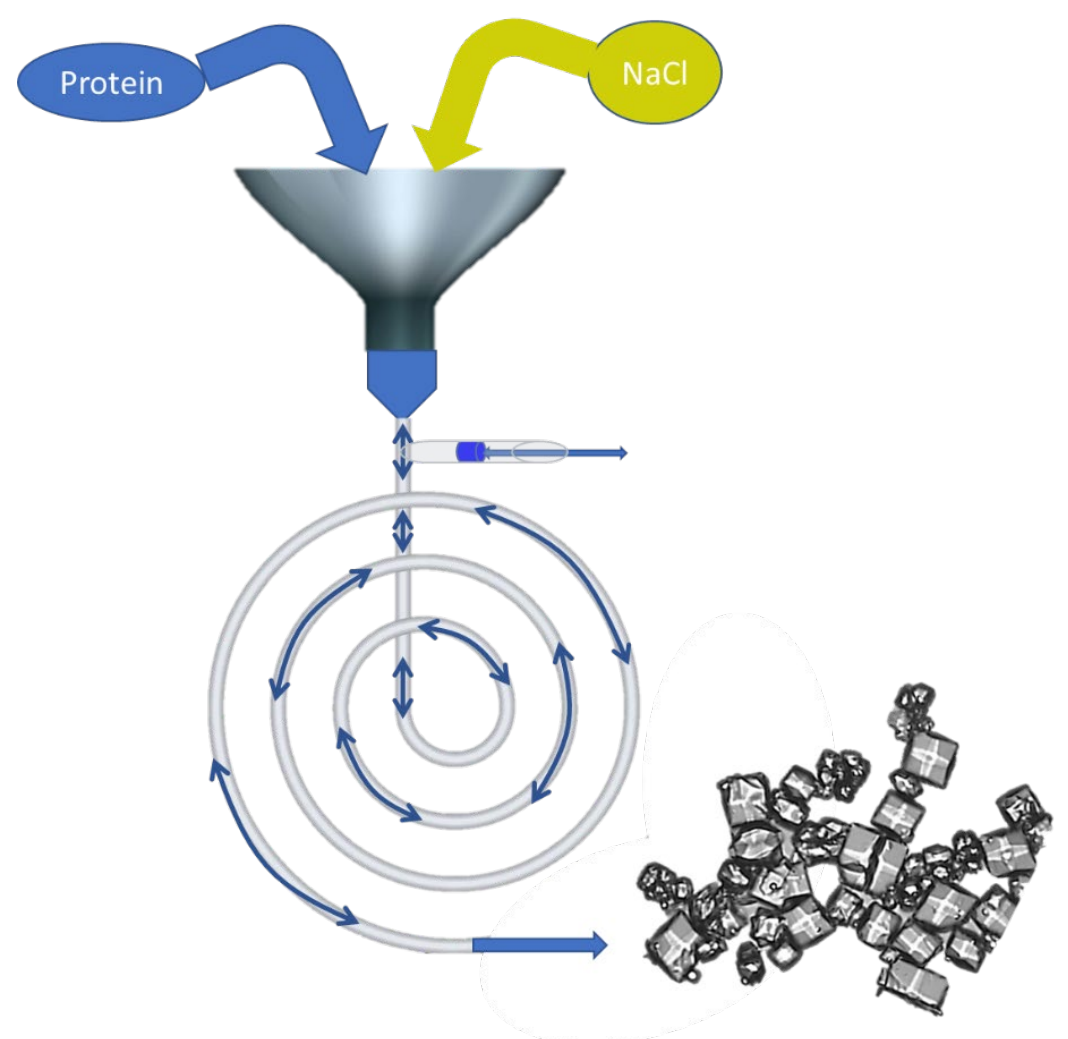

- A guiding workflow for developing continuous protein crystallisation

- A successful development of continuous lysozyme crystallisation: micro L (hanging drop) $\rightarrow \mathrm{mL}$ (shaking platform) $\rightarrow 100 \mathrm{~mL}$ (oscillatory flow platform)

- Good crystal shape and high bioactivity for product obtained in continuous crystallisation 